\title{
MOLINISM AND THEOLOGICAL COMPATIBILISM
}

\section{CHRISTOPH JÄGER}

University of Innsbruck

\begin{abstract}
In a series of recent papers John Martin Fischer argues that the socalled Molinist solution to the problem of reconciling divine omniscience with human freedom does not offer such a solution at all. Instead, he maintains, Molina simply presupposes theological compatibilism. However, Fischer construes the problem in terms of sempiternalist omniscience, whereas classical Molinism adopts atemporalism. I argue that, moreover, an atemporalist reformulation of Fischer's argument designed to show that Molinism is not even consistent is unsuccessful as well, since it employs a transfer principle about causal inaccessibility that Molina rightfully rejects.
\end{abstract}

\section{INTRODUCTION}

In a series of recent papers John Martin Fischer argues that the so-called Molinist solution to the problem of reconciling divine omniscience with human freedom does not even attempt to offer a response to this problem (Fischer 2008, 2009, 2011). 'I intend to show', he writes, 'that [the kernel set of ideas in Molina's theory of God's omniscience] ... (contrary to what many philosophers apparently think) cannot be invoked to provide a solution to the problem posed by the relationship between God's omniscience and human freedom' (2011:208). Instead of presenting such a solution, Fischer maintains, Molinism simply presupposes theological compatibilism since it assumes 'from the outset ... that there exists a possible world in which God knows in advance that some agent does $\mathrm{X}$ and is nevertheless free to do otherwise' (2009: 138-39). Molinism, he argues, is thus 'question-begging (or at least not dialectically helpful at all)' for the dispute over theological compatibilism (2011:213; 2008: 28).

Fischer raises an important question here, and his reflections are (as so often) helpful and stimulating. Indeed, at first blush it might appear 
not only that his argument is on target, but that he is obviously right. After all, is it not a consequence of 'middle knowledge' (scientia media), the key concept of Molinism, that if God holds such knowledge He thereby knows what some possible creature would freely do in some possible situation? Middle knowledge, Molina says in an oft-quoted passage, is a kind of divine knowledge

by which, in virtue of the most profound and inscrutable comprehension of each faculty of free choice, He [God] saw in His own essence what each such faculty would do with its innate freedom were it to be placed in this or in that or, indeed, in infinitely many orders of things ... ${ }^{1}$

As Molina defines it, middle knowledge constitutes divine knowledge of free human actions, and hence it may indeed look as if Molina, in assuming that the notion of middle knowledge is coherent at all, just posits the truth of theological compatibilism.

However, on closer inspection the picture turns out to be somewhat different. First, Fischer discusses and criticizes what we may call sempiternalist Molinism - the view that an everlasting God has both middle knowledge and genuine foreknowledge, the latter concerning events which also from God's point of view are still coming to be. There may be such forms of Molinism, yet they differ from paradigmatic or classical versions of Molinism. Arguably, the most classical version of Molinism is the account put forth by Molina himself. To be sure, Molina often uses temporal lingo when presenting his theory. But his official position - like that of most late medieval Aristotelians heavily influenced by Aquinas - is theological atemporalism. Accordingly, what Molina argues for is what I shall call atemporalist Molinism. Fischer argues that Molinism does not offer a response to what he calls 'the Basic Argument' for the incompatibility of God's (sempiternal) omniscience with human freedom (2011: 212). However, classical Molinism has a straightforward response to this argument as laid out by Fischer: divine knowledge does not occur at times at all; from an atemporalist viewpoint Fischer's Basic Argument is ill-phrased.

1 '... mediam scientiam qua ex altissima et inscrutabili comprehensione cuiusque liberi arbitrii in sua essentia intuitus est, quid pro sua innata libertate, si in hoc vel illo vel etiam infinitis rerum ordinibus collocaretur, acturum esset ...' (Concordia, disp. 52, 9; p. 340/p. 168, emphasis in the English translation C.J.) Here and in what follows the English translations follow Freddoso's, with page references, in this order, to Rabeneck's latin edition of the Concordia and Freddoso's translation. 
Of course, whether this response succeeds depends, among other things, on whether atemporalism is true (or at least rationally acceptable). This question is controversial. This paper does not aim to enter into this general controversy between temporalists and atemporalists. Instead I shall reconstruct Fischer's Basic Argument, clarify Molina's position, and then show in some detail why the Basic Argument for theological incompatibilism does not apply to Molina's atemporalist conception of divine middle knowledge. A natural question at this point is whether Fischer's charge can be restated in atemporalist terms. In a second step I argue that what most threatens Molina's atemporalist Molinism in this context is an argument to the effect that his position is not even consistent. As it turns out, however, Molina has a response to this charge as well.

\section{FISCHER'S BASIC ARGUMENT FOR THEOLOGICAL INCOMPATIBILISM, AND ATEMPORALIST MOLINISM}

What exactly is the 'Basic Argument' for theological incompatibilism which, according to Fischer, Molina does 'not even attempt' to respond to? (2008: 25) Fischer notes, first, that 'whatever else omniscience involves, it entails that an omniscient agent believes P just in case P is true' (2011: 211). Since Fischer's argument will adopt theological sempiternalism and make the (standard) assumption that God is essentially omniscient, we may capture the relevant principle by saying that:

(Omniscience) If $\mathrm{A}$ is essentially sempiternally omniscient, then, necessarily, for any given time $\mathrm{T}$ and proposition $\mathrm{P}$, $\mathrm{A}$ believes at $\mathrm{T}$ that $\mathrm{P}$ if and only if $\mathrm{P}$.

Next, Fischer introduces a principle designed to capture the fixity of the past, or the view that what one is able, or has in one's power, to do must be an extension of the actual past. Hence:

$\left(\mathrm{FP}^{\star *}\right)$ 'An agent $\mathrm{A}$ has it in his power (in the sense relevant to moral responsibility) at (or just prior to) $\mathrm{T}$ in possible world $\mathrm{W}$ to do $\mathrm{F}$ at $\mathrm{T}$ only if there is a possible world $\mathrm{W}^{\star}$ with the same past as that of $\mathrm{W}$ up to $\mathrm{T}$ in which A does $\mathrm{F}$ at T. (2011: 211; 2009: 129 , footnote 8$)^{2}$

Inspired by Nelson Pike's classic argument for theological incompatibilism (cf. Pike 1965), Fischer then formulates his argument as follows:

${ }^{2}$ Fischer uses $\mathrm{S}, \mathrm{X}$, and $\mathrm{t}$ where I use A, F, and T, respectively. 
'Suppose that God ... exists, and that $\mathrm{S}$ does $\mathrm{X}$ at $\mathrm{t}_{2}$, where $\mathrm{X}$ is some ordinary act such as raising one's hand. It follows that God believed at $t_{1}$ that $S$ would do $X$ at $t_{2}$. Given God's essential omniscience, God's belief at $t_{1}$ entails that $S$ does $X$ at $t_{2}$. Thus, in all possible worlds in which God believes at $t_{1}$ that $S$ will do $X$ at $t_{2}$, $S$ will do $X$ at $t_{2}$; so in any world in which $S$ does not do $X$ at $t_{2}$, God doesn't believe at $t_{1}$ that $S$ does $X$ at $t_{2}$. It seems to follow from $\left(\mathrm{FP}^{* *}\right)$ that $\mathrm{S}$ does not have it in his power at or just prior to $t_{2}$ to refrain from $X$-ing at $t_{2}$.' (2011: 211f.; 2009: 129)

It may be helpful to examine a somewhat more schematic presentation of this 'Basic Argument' for theological incompatibilism. Suppose that $\mathrm{S}$ does $\mathrm{X}$ at $\mathrm{t}_{2}$ and that God exists and is essentially and sempiternally omniscient (assumption). It follows, first, that:

\section{(Argument I)}

(1) God believes at $t_{1}$ that $S$ will do $X$ at $t_{2}$. Moreover, by (Omniscience) we get:

(2) Necessarily, if God believes at $t_{1}$ that $S$ will do $X$ at $t_{2}$, then $S$ does $\mathrm{X}$ at $\mathrm{t}_{2}$.

If (1) is true, and we count refraining from doing $X$ as doing something (which I do not wish to dispute), we can deduce with (FP ${ }^{\star *}$ ) that:

(3) $S$ has it in his power (or is in this sense free) at or just prior to $t_{2}$ to refrain from doing $X$ at $t_{2}$, only if it is possible that: God believes at $t_{1}$ that $S$ will do $X$ at $t_{2}$, but $S$ refrains from doing $X$ at $t_{2}$.

However, (2) is of course just another way of saying that:

(4) It is not possible that: God believes at $t_{1}$ that $S$ will do X at $t_{2}$, but $S$ refrains from doing $\mathrm{X}$ at $\mathrm{t}_{2}$.

From (3) and (4) it follows (by contraposition and modus ponens) that:

(5) $S$ does not have it in his power at or just prior to $t_{2}$ to refrain from doing $\mathrm{X}$ at $\mathrm{t}_{2}$.

However, Molina holds a robust libertarian theory of free will and moral responsibility which endorses the principle of alternate possibilities, according to which an action is free ('in the sense relevant to moral responsibility') only if the agent could have done otherwise. On this view, therefore (5) also tells us that $S$ is not free in doing what he does at $t_{2}$.

What are we to say of this argument and its significance for classical Molinism? First, Molina would dismiss this argument straightforwardly because he adopts atemporalism. Second, one may question the relevance of the above argument for what Fischer - rightly, I believe - identifies 
as the key question in this context. This question is whether we enjoy power to do otherwise in the sense relevant to moral responsibility (see $\mathrm{FP}^{\star *}$ above). But whatever the above argument (1)-(5) achieves, I do not think that in its present form it shows that foreknowledge is incompatible with the power to do otherwise in this sense. In order to achieve that conclusion, it would have to show, first, that $S$ does not have it in his power at or just prior to $t_{2}$ to refrain from doing $X$ at $t_{2}$ and, second, that $S$ does not have a choice (at or just prior to $t_{2}$ ), nor ever had a choice, about lacking that power at or just prior to $t_{2}$. In order for this condition to be fulfilled, however, the argument would have to maintain that $S$ does not have, nor ever had, a choice about God's believing at $\mathrm{t}_{1}$ that $\mathrm{S}$ would do $\mathrm{X}$ at $t_{2}$. I begin with the first point, which concerns Molina's atemporalism.

(i) Molina makes it very clear in the Concordia that, concerning the concept of eternity, he wishes to follow Aquinas, Augustine, Boethius, Anselm, and others in construing the notion in an atemporalist sense. In disp. 48, for example, he discusses 'whether all the things that exist, have existed, and will exist in time are present to God from eternity' (which is part of the title of disp. 48). His answer is affirmative, and he explains that:

eternity is in itself a certain indivisible duration, a simultaneous whole having as a unit an infinite durational latitude by virtue of which it coexists and corresponds as a whole with the whole of time and as a whole with each interval and point of time. ... [T] he whole of time and whatever exists or successively comes to exist in it coexists with and exists in the indivisible now of eternity, before which there is nothing and after which there is nothing, and in which there is found no before or after and no past or future, but only an indivisible, simultaneously whole duration. ${ }^{3}$

Molina proceeds by quoting 'the holy Fathers' who, he explains, 'sometimes deny that in God there is foreknowledge, properly speaking'.

For in the indivisible now of eternity, which is the duration proper to the divine knowledge, all things are present and coexist; and in this eternal now there is no before or after ... So it follows that in God there is no foreknowledge with regard to the existence of things in eternity. ${ }^{4}$

3 'Aeternitas ... sit secundum se duratio quaedam indivisibilis tota simul unite habens latitudinem durativam infinitam qua coexistit et correspondet tota toti tempori et tota singulis partibus ac punctis illius ... [T] otum tempus et quicquid in eo est aut fit successive coexistat et sit in indivisibili nunc aeternitatis, ante quod nihil est et post quod nihil aliquid non est, in quo neque cernitur prius aut posterius neque praeteritum aut futurum, sed duratio indivisibilis tota simul.' (Concordia, disp. 48, 2, p. 300/p. 99) 
And Molina goes on approvingly to quote Augustine, Anselm, and Boethius on this view.

The idea that things with temporal existence may be said in some sense also to exist in timeless eternity may raise an eyebrow. Here I shall not comment further on this issue, but simply note that Molina's official position is atemporalism, and that he agrees with the Augustine-Boethius-Aquinas tradition that 'properly speaking' there is no foreknowledge in God. So at least Molina's Molinism has a response to the Basic Argument, namely that it (mis)construes divine knowledge of human action as a kind of knowledge that occurs in time.

To be sure, when he talks about divine knowledge Molina frequently slips into temporal lingo. For example, in the passage just quoted, where he denies that there is foreknowledge in God regarding 'the existence of things in eternity', he goes on to say: '... though in relation to time there is, altogether properly speaking, foreknowledge in God, since He knows things an infinitely long time before they exist.' ${ }^{5}$ What Molina means, however, is that such temporal qualifications of divine actions and cognitive states are to be taken nostro intelligendi modo, i.e., in our way of understanding (and speaking). Only from the perspective of temporal beings may one say that there were times when God knew - knew in eternity - what people were going to do. Only in this sense were there times, for those temporal beings, when God in His atemporal eternity held true beliefs about what would happen.

4 ' $[\mathrm{I}] \mathrm{n}$ indivisibili nunc aeternitatis quod est propria duratio scientiae divinae omnia sint praesentia et coexistant neque in eo sit prius et posterius ... [F] it ut comparatione existentiae rerum in aeternitate non sit praescientia in Deo.' (Concordia, disp 48, 11, pp. 302-303/p. 103; emphasis in the English translation added.) The Concordia contains so many passages in which Molina argues along such lines that it is impossible to quote them all here. When Molina speaks of 'eternity', he almost always refers to timeless eternity. To mention just one other representative passage, in disp. 51, 17, Molina says that in eternity, insofar as it corresponds to this present time or any past moment of time, either God sees with certainty, because of the depth and perfection of His knowledge, which part Peter's free choice is going to turn itself toward tomorrow, or He does not see this with certainty. The second answer cannot be given ....' ('Deus in aeternitate, ut respondet huic praesenti aut cuicumque praeterito temporis momento, ex altitudine et perfectione suae scientiae penetrat certo, in quam partem liebrum arbitium Petri se inflectet castina die vel non. Non est dandum hoc secundum.' (p. 333/ p. 156; emphasis in the English translation added C.J.)

${ }^{5}$ '... tametsi collatione facta ad tempus sit in Deo propriissime praescientia qui res scit tempore infinito, anteaquam sint.' (Molina, Concordia, disp. 48, 11, pp. 302-303/p. 103) 
Note that both contemporary friends and foes of Molinism usually emphasize that according to Molina middle knowledge occurs 'prevolitionally' in God and thus enjoys some kind of priority over the knowledge which God has once He engages in His creative voluntary act of actualizing the actual world. Yet what virtually all commentators (rightly) emphasize as well is that this priority ought not be (mis-) construed in a temporal sense, but is to be conceived as a 'logical' or 'explanatory' kind of priority. According to Molina, 'before' creation God has (a) 'natural knowledge' (scientia naturalis), i.e., knowledge of every necessary state of affairs, and (b) 'middle knowledge' (scientia media), by which He knows what every possible free creature would freely do when placed in certain circumstances. When He actualizes the actual world God also has, according to Molina, (c) 'free knowledge' (scientia libera), i.e., postvolitional knowledge of all the actual contingent states of affairs which from then on obtain in the actual world. ${ }^{6}$ However, commentators typically stress, and with good reason, that the corresponding stages of creation which Molinists distinguish should not be construed as referring to some temporal order, but as referring to a conceptual or explanatory kind of priority. We would not need this caveat if according to Molinism God's knowledge occurred at certain points in time. ${ }^{7}$ I conclude that, if this is how Molina sees the matter, he could, and should, immediately reject the basic assumption of the Fischer-Pike argument according to which there is sempiternal divine knowledge. Accordingly, he could immediately dismiss its central premise (1). God doesn't know anything at any time, but this is not because $\mathrm{He}$ is not omniscient. It is because $\mathrm{He}$ doesn't have knowledge at times.

In fact Fischer explicitly considers atemporalism as one of 'various ways to respond to the Basic Argument' (2011: 212). However, he apparently does not regard it as a route Molina could take: 'The kernel set of ideas in Molina's theory of God's omniscience ... cannot be invoked

${ }^{6}$ Cf. Molina, Concordia, disp. 52, 9, pp. 339-40/p. 168.

7 Freddoso, for example, emphasizes more than one time that the characterization of the three kinds of divine knowledge as prevolitional and postvolitional ought not to be misconstrued in a temporal sense. (See for example Freddoso 1988: 3, footnote 3: 'By dubbing such knowledge prevolitional I mean to point to a conceptual or logical, rather than temporal, ordering within the divine knowledge. Here I follow Molina.') He also emphasizes Molina's 'strong adherence to the doctrine that God is eternal [in an atemporalist sense]', and notes that, unfortunately, this 'does not deter him [Molina] from using tensed language when speaking of God's knowledge of and causal influence on temporal creatures.' (Freddoso 1988: 33-34) 
to provide a solution to the problem posed by the relationship between God's omniscience and human freedom' (2011:208). However, if Fischer's first claim (about atemporalism as a possible response) is true then this latter claim is false, given that atemporalism is among the central tenets of Molina's account, and that it is consistent with it.

It often seems as if Fischer identifies Molinism with Molina's claim that there is divine middle knowledge. This identification is inaccurate, it may be argued, since it does not pay much tribute to the richness and complexity of Molina's views. However, Fischer explicitly concedes this and says that his aim is 'not to do history of philosophy or textual exegesis, but, rather, to lay out and philosophically evaluate a certain set of views' (2011: 209). Moreover, whatever we may say about various other aspects of Molina's overall philosophy of providence and freedom, why should we not sever his theological atemporalism from his theory of middle knowledge? Wouldn't this move allow Fischer to maintain that Molinism, reduced to the theory of middle knowledge, indeed fails to provide a response to the Basic Argument?

The problem with this reply is that Molina does seem to regard his notion of middle knowledge as being essentially embedded in his overall atemporalist theology. By middle knowledge, he says, God knows in His own essence what each free creature would freely do in any given circumstance (cf. our first quote from Molina above in section 1). But if God exists in timeless eternity, this is part of His essence. Whatever His mode of existence, it does not pertain to Him contingently. Hence Molina's atemporalism is not just a ramus amputandus of his theory of middle knowledge. As the account has it, God knows essentially in timeless eternity what every possible free creature would freely do in any possible circumstance. So, the dispute is not just about the label 'Molinism'. Even if we identify classical 'Molinism' with Molina's theory of middle knowledge, since this theory concerns atemporalist divine knowledge, it does contain a response to Fischer's sempiternalist Basic Argument.

(ii) I turn now to the second problem with the Fischer-Pike argument for theological incompatibilism. Fischer claims that the Basic Argument pertains to the power to do otherwise in the sense relevant to moral responsibility' (see $\mathrm{FP}^{\star *}$ ). Hence the desired conclusion of the Basic Argument is that $S$ does not have the power to refrain from doing $\mathrm{X}$ at $\mathrm{t}_{2}$ and is thus not morally responsible for doing $X$ at $t 2$. Fischer is certainly right on this point. What worries philosophical theologians 
since St. Paul $^{8}$ is whether, and on what grounds, humans may be held accountable for their deeds, and how they can be said to sin, if all of their actions are foreseen by God. Unfortunately, however, Fischer's Basic Argument, as it stands, does not yield the conclusion that $S$ is not morally responsible for doing $\mathrm{X}$ at $\mathrm{t}_{2}$. Given Molina's libertarianism and his acceptance of the principle of alternate possibilities, in order to allow that conclusion, the argument would have to show in addition that $S$ has no choice about whether God knows at $t_{1}$ that $S$ is going to do $X$ at $t_{2}$. Consider the following example from van Inwagen:

Suppose that when I am drunk it is not within my power to refrain from violently assaulting those who disagree with me about politics. I get drunk and overhear a remark about Cuban troops in Angola and, soon, therefore, Fred's nose is broken. I was, under the circumstances, unable to refrain from breaking Fred's nose. And yet no one doubts that I am to blame for his broken nose. How can that be? Simple: Although I was unable to avoid breaking his nose, that inability is one I could have avoided having (van Inwagen 1989: 236).

In these circumstances, van Inwagen would be to blame for breaking Fred's nose because he would be morally responsible for it (and because, let us assume, his action is morally reprehensible). The latter holds because, even though given the antecedent conditions of his action he does not have the power to refrain from acting as he does at the time in question, nothing rules out that he had a choice about whether these antecedent conditions obtained. A similar point applies to Fischer's Basic Argument. If it wants to establish that $\mathrm{S}$, due to lacking the power to do otherwise at $t_{2}$, is not morally responsible for doing $X$ at $t_{2}$, the conclusion would have to be that $S$ does not have it in his power at or just prior to $\mathrm{t}_{2}$ to refrain from doing $\mathrm{X}$ at $\mathrm{t}_{2}$ and does not have, nor ever had, a choice about this lack of power because $\mathrm{S}$ does not have, nor ever had, a choice about the (sufficient) antecedent conditions of his action. The Basic Argument would therefore have to reason from the premise that $S$ does not have, nor ever had, a choice about God's believing at $t_{1}$ that $\mathrm{S}$ will do $\mathrm{X}$ at $\mathrm{t}_{2}$. Molina, however, rejects such claims. 'It is not', he writes, 'because God foresees these things as future that they are going to be; rather, it is because they are going to be, by virtue of created free choice, that they are foreseen as future by God' (Concordia, disp. 51, 4; p. 328/p. 149). According to this view, therefore, there was a time, after all,

\footnotetext{
${ }^{8}$ See for example his discussion of the fate of Jacob and Esau in Romans 9: 11-13.
} 
when $S$ had a choice about God's foreknowing that $S$ would do $X$ at $t_{2}$. It was the time when $S$ decided to do $X$ at $t_{2}$, for, had $S$ decided at that time to refrain from doing $X$ at $t_{2}$, God would have believed that $S$ would refrain from doing $\mathrm{X}$ at $\mathrm{t}_{2}$.

Molina, I argued, endorses atemporalism. Hence we may read him here as claiming that, even if a sempiternalist argument for theological incompatibilism along the lines of Fischer's Basic Argument were acceptable and not to be dismissed from the outset, such an argument should be rejected because it gets the order of explanation wrong. Given Molina's atemporalism, however, I shall not pursue this sempiternalist response with respect to Fischer's original argument. Instead, I shall now turn to atemporalist Molinism and ask whether an argument in Fischer's spirit might be reformulated on such classical Molinist grounds.

\section{IS ATEMPORALIST MOLINISM COHERENT?}

A natural view is that an action is performed freely - in the sense relevant to moral responsibility - only if the agent is, at least in part, causally responsible for it or, as I shall say, has a causal impact on it. We may capture this in the following principle:

(CI) A human agent A performs an action freely only if A contributes causally to it.

(CI), I contend, states a moderate and highly plausible necessary condition for an action to be free. It is hard to see how an action whose agent has no causal influence whatever upon it should qualify as having been performed freely. Indeed, many authors would say that in such a case it doesn't even qualify as an action at all.

Not only is (CI) systematically very plausible, it also is a tenet of classical Molinism. Along with Aquinas and many other late medieval authors Molina holds that, while God is the primary (or remote) cause of every contingent state of affairs, free human actions are such that their agents serve as secondary (or proximate) causes of them. Any free creaturely action, on this view, is such that its agent causally contributes to performing it (as a secondary cause), thereby giving God's 'general concurrence' which makes that action possible at all a particular direction. While human agents do not, and cannot, see to it that all necessary conditions for their free actions are fulfilled, freedom nevertheless requires agents to be causally involved in those actions. Regarding Molina's way of phrasing the problem, it will be helpful to 
formulate the following corollary of (CI). (CI) entails that, if an agent does not contribute causally to something he does, then what he does is not done freely. It follows that, if for metaphysical reasons an agent cannot contribute causally to some event, then even less does this event qualify as a free action of his. Now, let us say that, if an agent A cannot contribute causally to some event or state of affairs at a given time $t$, that event or state of affairs is 'causal-impact necessary' (CI-necessary) for A at $\mathrm{t}$. So we have:

(CI-Nec) An agent A performs an action freely at $t$ only if that action is not CI-necessary for $\mathrm{A}$ at $\mathrm{t}$.

A critic may argue that this principle can be deployed to show not only that (atemporalist) Molinism fails to respond to the charge of theological incompatibilism, but that the Molinist position is not even consistent. The argument can be presented as a reductio. ${ }^{9}$ Let $\mathrm{S}$ once more denote a given human agent, and suppose that $\mathrm{S}$, being in circumstances $\mathrm{C}$ at $\mathrm{t}$, does $\mathrm{X}$ at t. Suppose that God exists and is essentially atemporally omniscient (assumption), i.e., suppose that necessarily, if God eternally believes that $\mathrm{p}$ then $\mathrm{p}$, and vice versa. (From now on I use 'eternal', 'eternity', and so forth, exclusively in an atemporal sense.) The anti-Molinist's reasoning might then go as follows. According to Molina, he may argue, it holds that:

\section{(Argument II)}

(1) It is CI-necessary for S (at any time in S's life) that God eternally believe via middle knowledge that $S$, when placed in circumstance $\mathrm{C}$ at $\mathrm{t}$, would freely do $\mathrm{X}$ at $\mathrm{t}$.

(2) Necessarily, if God eternally believes via middle knowledge that $S$, when placed in circumstance $\mathrm{C}$ at $\mathrm{t}$, would freely do $\mathrm{X}$ at $\mathrm{t}$, then $\mathrm{S}$, when placed in $\mathrm{C}$ at $\mathrm{t}$, freely does $\mathrm{X}$ at $\mathrm{t}$.

(3) Hence, it is CI-necessary for S (at any time in S's life) that, when placed in $\mathrm{C}$ at $\mathrm{t}$, he freely does $\mathrm{X}$ at $\mathrm{t}$.

However, (CI-Nec) tells us that an action is performed freely at $\mathrm{t}$ only if it is not CI-necessary for its agent at $t$. Hence, with this principle we can derive from (3) the self-contradictory statement that:

(4) $\mathrm{S}$ is not free in doing $\mathrm{X}$ freely when placed in $\mathrm{C}$ at $\mathrm{t}$.

Since (4) is contradictory, the above argument - if it goes through - is a reductio of Molina's atemporalist Molinism.

\footnotetext{
${ }^{9}$ For related versions see Jäger (2011a) and (2011b).
} 
Molinists have at least two responses to this argument. The first concerns premise (1). How might Molina's opponent back up this premise? Theological considerations aside, a natural line of reasoning is that, just as we cannot control the past, nor can we influence the realm of the timeless. But why do we lack control over the past? Because, the reasoning may go, we cannot causally influence it. And the reason usually presented for this is that backward causation is impossible. ${ }^{10}$ Backward causation is a process type in which a cause occurs later in time than its effect, and we tend to be sceptical about backward causation because we assume that precisely this must not be allowed. Note however that this argument does not rule out that temporal beings can have a causal impact on something in the realm of the timeless. For temporal beings and their actions and decisions certainly do not occur later in time than timeless states of affairs. In short, our denial of causal access to the past seems to be grounded in a no-later-in-time requirement for causes; yet a parallel argument does not work for denying that it is possible to have a causal impact on what God eternally believes about human actions.

There are other reasons for claiming that we cannot have a causal impact on what occurs outside time. A standard argument is that in a cause-effect relation both relata must be temporal entities. The problem with this argument, however, is that it would also preclude a timeless God from causally affecting the temporal world. To be sure, this is one of the main philosophical reasons anti-eternalists have traditionally put forth in favour of sempiternalism. ${ }^{11}$ Yet the issue is highly controversial, and Molina is an atemporalist. So if we assume, with classical Molinism and many other authors in the Augustine-Boethius-Aquinas tradition, that God is timeless yet can still causally interact with His creation as it unfolds in time, there is no reason, at least no obvious philosophical one, to object to the idea that causation may also proceed from inside to outside of time. I conclude that, from the point of view of classical atemporalist Molinism, good reasons for premise (1) in Argument II are thin on the ground.

10 The following argument draws on Zagzebski (2011: 73).

${ }^{11}$ Cf. for example Swinburne (1993a), chapter 12; and (1993b). In this latter work Swinburne argues that 'if God causes the beginning or continuing existence of the world, and perhaps interferes in its operation from time to time, his acting must be prior to the effects that his action causes' (p. 216). Concerning Stump and Kretzmann's atemporalism and their notion of 'ET-simultaneity' (Stump and Kretzmann 1993), Swinburne argues that 'no reason has been given for supposing that if God has an existence outside (our) time, he can have any relation to the events of time which would be in any way analogous to "causing" or "observing" them' (p. 218). 
Molina's second response to Argument II could be that, whatever we may say about premise (1), the inference from (1) and (2) to (3) is dubious as well. This inference relies on a closure or transfer principle that is structurally analogous to the necessity version of van Inwagen's famous principle Beta. ${ }^{12}$ The inference from (1) and (2) to (3) in Argument II relies on the rule that:

(Transfer) If an agent A cannot have, and could never have had, a causal impact on $\mathrm{p}$ (or on an event that grounds the truth of $\mathrm{p}$ ), and necessarily, if $\mathrm{p}$ then $\mathrm{q}$, then A cannot have, nor could ever have had, a causal impact on $q$ (or on an event that grounds the truth of $\mathrm{q}$ ).

The qualification 'or an event that grounds ... is meant to preserve neutrality towards particular theories of causation. Some will say that, since propositions are abstract objects and thus do not exist in time, one cannot have a causal impact on them. However, even if one accepts an inside-time requirement for the relata of causation, we could still say that agents can have a causal impact on events which are such that, if they occur, certain corresponding propositions are true.

Does Molina accept (Transfer), and is this principle true? I think that both questions are to be answered in the negative. The interpretative question is somewhat complex, and here I shall only give its bare outlines. ${ }^{13}$ In disp. 52 of the Concordia Molina explicitly discusses and rejects seven arguments in favour of theological incompatibilism. (This is one more reason why one might hesitate to accuse Molina of not even attempting to explain how divine omniscience might be compatible with human freedom.) Some of these arguments bear close similarities to Fischer's Basic Argument. For example, Molina asks us to consider a line of anti-compatibilist reasoning he reconstructs as follows:

If a conditional is true and its antecedent is absolutely necessary, then its consequent is likewise absolutely necessary; otherwise, in a valid consequence, the antecedent could be true and the consequent false, which is in no way to be admitted. But the conditional 'If God knew that this was going to be, then it will so happen' is true, or else God's knowledge would be false; and the antecedent is absolutely necessary, both because

\footnotetext{
${ }^{12}$ See van Inwagen (1983: 94). The original principle has the form: Np, N(p $\supset$ q) - $\mathrm{Nq}$, where ' $\mathrm{Np}$ ' is, in one application, to be read as saying that $\mathrm{p}$, and no one has (or ever had) a choice about whether $\mathrm{p}$.

${ }^{13}$ For a more extensive treatment, however, see Jäger (2011a).
} 
it is eternal and because it is past-tense and there is no power over the past. Therefore, the consequent will be absolutely necessary as well, and hence no future thing foreknown by God will be contingent. ${ }^{14}$

Some comments are in order. First, as Molina makes clear in his reply to this argument (to be quoted soon), what is really at issue here is not just a 'true' conditional but one that is necessary. For clearly, it is not only true but necessarily true - true for conceptual reasons - that, if God knew that $\mathrm{X}$ was going to happen, $\mathrm{X}$ would happen. The conditional in question, the 'valid consequence', as Molina says, thus has the form $\square$ (p $\supset$ q). Second, whereas the kind of necessity pertaining to the conditional as a whole is metaphysical or 'broadly logical necessity', the 'absolute', that is, nonconditional necessity of the antecedent (i.e., of 'God knew that this was going to happen') is of a different kind. After all, the antecedent is said to be necessary 'both because it is eternal and past.' This would not be a good reason to count this proposition as (broadly) logically necessary. The question is exactly which kind of non-logical necessity and which kind of transfer principle concerning mixed modalities is at issue. Let ' $N$ ' stand for the kind of non-logical necessity in question. The text of the above quotation is indifferent as to whether the transfer principle in question is of the form: $\mathrm{Np}, \square(\mathrm{p} \supset \mathrm{q}) \mid-\square \mathrm{q}$, or of the form: $\mathrm{Np}$, $\square(\mathrm{p} \supset \mathrm{q}) \mid-\mathrm{Nq}$. Given that 'N' will in any case be an operator denoting some weaker kind of necessity than logical necessity, the former principle is quite obviously false. Hence what is under consideration, it seems, is the truth of a principle of the form Np, $\square(\mathrm{p} \supset \mathrm{q}) \mid-\mathrm{Nq}$.

Molina responds to the argument by rejecting its inference as invalid, thereby rejecting the modal transfer principle it employs. His response is that:

In such a case, even if (i) the conditional is necessary (because in the composed sense these two things cannot both obtain, namely, that God foreknows something to be future and that the thing does not turn out that way), and even if (ii) the antecedent is necessary in the sense in

14 'Si conditionalis aliqua est vera et eius antecedens est absolute necessarium, consequens est etiam absolute necessarium; alioquin in bona consequentia esse posst antecedens verum et consequens falsum, quod nulla ratione est admittendum. Sed haec condicionalis est vera: si Deus scivit hoc esse futurum, id ita eveniet, alioquin scientia Deo esset falsa; et antecedens est absolute necessarium, tum quia aeternum, tum etiam quia praeteritum et ad praeteritum non est potentia. Ergo consequens erit etiam absolute necessarium ac proinde nullum futurum praescitum a Deo erit contingens.' (Concordia, disp. 52, 3, pp. 337-8/pp. 167-8) 
question (because it is past-tense and because no shadow of alteration can befall God), nonetheless the consequent can be purely contingent. ${ }^{15}$

So he agrees with his opponent that the conditional is necessary necessary in the (broadly) logical sense, we may interpret him - and that the antecedent is necessary in some other sense. Yet he disagrees that from this we can deduce that the consequent is necessary - necessary in that other sense - as well. Molina, in other words, denies that the rule $\mathrm{Np}, \square(\mathrm{p} \supset \mathrm{q}) \mid-\mathrm{Nq}$ is valid for the kind of necessity for which ' $\mathrm{N}$ ' stands. It remains to be answered what kind of necessity applies in the argument's antecedent, the claim that God 'foreknows' that a certain event, for example some human action, is going to happen.

Various interpreters, including Freddoso, argue that what Molina denies here is that so-called 'accidental necessity' is closed under entailment, and that Molina therefore thinks that incompatibilist arguments which rely on the idea that accidental necessity is so closed are invalid. ${ }^{16}$ As introduced by William of Sherwood, accidental necessity is a time-relative kind of necessity pertaining to propositions or states of affairs that are past and thus 'over and done with. ${ }^{17}$ If a state of affairs is accidentally necessary, no one can affect it anymore. If this interpretation were correct, we might have the potential for a reply to Fischer's sempiternalist version of the Basic Argument. However, given Molina's atemporalism and his characterization of the antecedent of the argument in question as 'eternal', I think that this interpretation is doubtful. Instead, I think that Molina may plausibly be interpreted as denying that causal-impact necessity is closed under entailment. Molina, it seems, denies (Transfer). After all, why might one think that the antecedent of the argument in question (that God knew that this was going to be) is in some sense necessary on account of its both being (i) 'eternal' and - nostro intelligendi modo - (ii) 'past-tense'? A natural reason

15 'Tunc enim, esto conditionalis sit necessaria, quia in sensu composito cohaerere non possunt ista duo, quod Deus aliquid praesciat futurum et illud non eo modo eveniat, et esto antecedens illo modo sit necessarium, quia praeteritum et quia in Deum nulla possit cadere vicissitudinis obumbratio, nihilominus consequens potest esse mere contingens.' (Concordia, disp. 52, 34, p. 353/p. 189)

${ }^{16}$ Freddoso (1988: 55); see also Zagzebski (1991: 131-32), and Zagzebski (2002).

17 According to William of Sherwood 'that is accidentally necessary which neither now nor in the future can be false, but once might have been false'. ('Necessarium autem per accidens est, quod non potest nec poterit esse falsum, potuit tamen'; Introductiones Logicam, 11, p. 34.) 
is that both what is past and what is atemporally eternal are causally inaccessible. To summarize: There is a highly plausible reading of Molina according to which he denies, in his response to a certain argument for theological incompatibilism, that what I called causal-impact necessity is closed under entailment. And this, I maintain, also yields a response to Argument II above, which in its inference from (1) and (2) to (3) employs a principle according to which causal-impact necessity is closed under entailment.

There may be some room for interpreting Molina's writings on the issue. However, the crucial systematic question at this point is whether (Transfer) really is invalid. And whatever Molina's views on this question may have been, I think that it should be answered in the positive. Somewhat ironically, we may support this verdict by considering a type of counterexample that Fischer himself once used to refute the claim that a related notion, namely that of moral responsibility, is closed under entailment. ${ }^{18}$ Some 400 years after the second edition of the Concordia appeared in print (in 1595), a fellow Jesuit of Molina's, Mark Ravizza S.J., presented counterexamples to the responsibility version of van Inwagen's famous rule Beta which draw on cases of causal overdetermination (Ravizza 1994). A few years later, Stump and Fischer reformulated Ravizza-style counterexamples in such a way that they would also fit the necessity version of rule Beta, as applied to moral responsibility. A very similar kind of counterexample, I maintain, can also be used to show that (Transfer), which concerns, not (lack of) moral responsibility, but what I called 'causal-impact necessity', is invalid. Here is an example of my own, based on Agatha Christie's story 'Murder on the Orient Express'.

The ingenious detective Hercule Poirot finds out that Mr. Ratchet has been stabbed to death by twelve different conspirators (by Princess Natalia Dragomiroff, Hector Willard McQueen, Colonel Arbuthnot, Hildegard Schmidt, and others). Each had a motive and stabbed the victim. We can easily retell the story in such a way that (i) each stabbing was causally sufficient for Ratchet's death, and that (ii) each stabbing caused his death via deterministic causal chains. Moreover, let us stipulate that (iii) none of the protagonists could have had any causal influence on any of their allies' lethal actions. In these circumstances, for each conspirator, the stabbing performed by any of his or her fellow murderers is CI-necessary.

18 See for example Stump and Fischer (2000). Such examples are also discussed in Fischer and Ravizza (1998). 
Second, by stipulation it holds that, necessarily: If one of the stabbings is performed, the victim will die; there is no possible world with the same laws of nature in which the victim is stabbed by any one of the agents but survives. However, Ratchet's death is not CI-necessary for any of the murderers, since each of them was causally involved in that event. Ex hypothesi each individual act of stabbing was causally sufficient for the victim's death. This is a counterexample to (Transfer). We have instantiations of the facts that it is CI-necessary for a given agent that $p$; necessarily, if $p$ then $q$; yet it is not CI-necessary for that agent that $q$. Given that Fischer endorses structurally similar counterarguments to similar transfer principles, I think that he should also accept this counterexample to (Transfer). In any case, this example seems to me to succeed against (Transfer), and hence it appears that Argument II against atemporalist Molinism, which at first glance seemed a promising fallback position for Fischer, should be rejected as well.

\section{MOLINA ON HUMAN CHOICE ABOUT DIVINE BELIEFS}

There is yet another string to the anti-Molinist's bow, one may argue, even if we assume atemporalism. For is not the question more generally whether human agents have a choice about divine beliefs about human actions, and whether these human agents can prevent God from forming these beliefs? ${ }^{19}$ If they cannot, the corresponding human actions would appear unavoidable too, and thus the problem would recur. Suppose we substitute, in Argument II, 'S never has a choice about the fact that ... for 'it is CI-necessary for S ... that .... Suppose again that S does X at $t$. The critic may then reason as follows:

(Argument III)

(1) S never (i.e., at no time in S's life) has a choice about the fact (or truth of the proposition) that God eternally believes via middle knowledge that $\mathrm{S}$, when placed in circumstance $\mathrm{C}$ at $\mathrm{t}$, would freely do $\mathrm{X}$ at $\mathrm{t}$.

(2) Necessarily, if God eternally believes via middle knowledge that $S$, when placed in circumstance $\mathrm{C}$ at $\mathrm{t}$, would freely do $\mathrm{X}$ at $\mathrm{t}$, then $\mathrm{S}$, when placed in $\mathrm{C}$ at $\mathrm{t}$, freely does $\mathrm{X}$ at $\mathrm{t}$.

(3) Hence, $S$ never has a choice about the fact (or truth of the proposition) that, when placed in $\mathrm{C}$ at $\mathrm{t}$, he freely does $\mathrm{X}$ at $\mathrm{t}$.

${ }^{19}$ I am indebted to Patrick Todd for this point. 
Following van Inwagen, let us say that, if $S$ has no choice about $p$, then $S$ cannot see to it that not-p, or - if $\mathrm{p}$ stands for a proposition - cannot render $p$ false. Now, on a libertarian conception of free will which accepts the principle of alternate possibilities it holds that:

(Choice) A performs an action freely at $t$ only if there is a time when A has a choice about performing that action at $t$.

With this principle we can again deduce from (3) the self-contradictory statement that:

(4) $\mathrm{S}$ is not free in doing $\mathrm{X}$ freely in $\mathrm{C}$ at $\mathrm{t}$.

This argument shows, Molina's opponent may maintain, that if we construe the atemporalist version of our anti-Molinist argument in terms van Inwagen's good old notion of lack of choice, the reductio goes through.

Argument III, too, employs a modal transfer principle which roughly has the form $\mathrm{N}_{\mathrm{s}} \mathrm{p}, \square(\mathrm{p} \supset \mathrm{q}) \mid-\mathrm{N}_{\mathrm{s}} \mathrm{q}$; only that this time the $\mathrm{N}$-operator, supplemented by a subject index and prefixed to $\mathrm{p}$, is to be interpreted in terms of there never being a choice for $S$ as to whether $\mathrm{p}$. Whether the nochoice operator is closed under entailment is not uncontroversial either; yet I concede that such a principle is harder to come by than (Transfer).

However, Molina has a response to Argument III as well. As already noted in section II, he frequently stresses that it would be a mistake to believe that we do what we do because God believes that we do it. Instead, he argues, God holds true beliefs about what we do because we (freely) do it. For example, consider the following two representative passages:

$\mathrm{He}$ [God] knows with certainty, before the determination of His will, what such-and-such a faculty of free choice would do in its freedom on the hypothesis and condition that God should create it and situate it in this particular order of things - even though it could, if it so willed, do the opposite, and even though if it was going to do the opposite, as it is able to, then God would have known this in His essence through that very same knowledge and comprehension, and not what He in fact knows is going to be done by that faculty of free choice. ${ }^{20}$

In disp. 52 Molina explicitly says that God knows what he knows about free creaturely actions because of these actions, and not vice versa:

20 '[A]nte illam determinationem voluntatis certo scit, quid tale liberum arbitrium sit facturum pro sua libertate ex hypothesi et condicione, quod illud creet et constituat in eo ordine rerum, cum tamen possit, si vellit, facere oppositum, et si esset facturum, ut potest, Deus illa eadem scientia et comprehensione liberi arbitrii in sua essentia scivisset et non id quo re ipsa scit a libero arbitrio esse agendum.' (Concordia, disp. 50, 15, pp. 32425/ pp. 140-41; emphases in the English translation added by Freddoso.) 
For ... the things that issue forth from our choice or depend on it are not going to happen because they are foreknown by God as going to happen, but, to the contrary, they are foreknown by God as going to happen in this or that way because they are so going to happen by virtue of our freedom of choice - though if they were going to happen in a contrary way, as they are able to, then from eternity they would be foreknown as going to happen in that contrary way instead of in the way they are in fact foreknown as going to happen. ${ }^{21}$

Adopting terminology recently suggested by Brüntrup and Schneider (2011) in a paper that discusses the present problem, we may say that, according to Molina, free creatures enjoy 'counterfactual power' over what God believes about their free actions. In a sense, we do have the power to make a possible world actual in which we do otherwise and in which, correspondingly, God holds different beliefs about what we do.

Molina, I believe, again argues from an atemporalist perspective when he says that human actions are 'from eternity foreknown' by God. Note however that the above passages could be read as containing yet another response to Fischer's sempiternalist Basic Argument. Suppose for the sake of argument that we adopt sempiternalist Molinism. Even then Molina's claims would in no way clash with the fixity of the past. Molina wholeheartedly endorses that the past cannot be changed: 'It manifestly involves a contradiction', he writes, 'for there to be power over the past.' ${ }^{22}$ This view is perfectly consistent with there being 'counterfactual power' over sempiternal divine beliefs. Consider the assumptions of the Basic Argument (that $\mathrm{S}$ does $\mathrm{X}$ at $\mathrm{t}_{2}$ and that God knows this in advance), and suppose that $\mathrm{S}$ is able to refrain from doing $\mathrm{X}$ at $\mathrm{t}_{2}$. What follows is not that, were $S$ to refrain from doing $X$ at $t_{2}, S$ would - per impossibile - change the actual past, including the fact that God knew at $\mathrm{t}_{1}$ that $\mathrm{S}$ would do $\mathrm{X}$ at $t_{2}$. What follows is only that, were $S$ to refrain from doing $X$ at $t_{2}$, the past would have been different from the way it actually was, and consequently that God would not have believed at $t_{1}$ that $S$ would do $X$ at $t_{2}$.

${ }^{21}$ 'Cum enim res quae a nostro arbitrio emanant aut ab eo pendent non ideo sint futurae, quia a Deo praecognoscuntur futurae, sed e contrario ideo a Deo praecognoscantur hoc vel illo modo futurae, quia ita pro libertate arbitrii sint futurae, quod si contrario modo, ut possunt, essent futurae, contrario etiam modo et non eo quo reipsa sciuntur praecognoscerentur ex aeternitate futurae.' (Concordia, disp. 52, 29, p. 349/p.184) Similar statements are frequent in the Concordia. For another passage see for example disp. 51, 4.

22 'Manifeste implicat contradictionem dari ad prateritum potentiam.' (Concordia, disp. 51, 19; p. 334/p. 158) 
In the above passages, Molina once more - and perhaps somewhat misleadingly - talks about divine 'foreknowledge'. Yet he also says that this knowledge is knowledge 'from eternity', by which he means atemporal eternity. So here as well, talk about 'foreknowledge' is to be understood nostro intelligendi modi. What Molina really argues, I maintain, is that human agents enjoy counterfactual power over timeless divine beliefs concerning human actions. It is in this sense, he believes, that human agents do have a choice about God's eternal beliefs and that therefore premise (1) of Argument III is false. S has a choice about God's (truly) believing, via middle knowledge, that $\mathrm{S}$ would do $\mathrm{X}$ at $\mathrm{t}$. For were $\mathrm{S}$ to act differently, a different counterfactual of freedom would be true, and consequently God would (eternally) have a different belief.

I think that this is a promising line of reasoning for Molina. Yet we should note the following problem. ${ }^{23}$ If we concede that human beings can have counterfactual power over divine beliefs, it might appear natural also to concede that we can have counterfactual power over the past or over laws of nature. The question, in other words, is whether the above quoted statements commit Molina to the view that, in a universe which is governed by deterministic causal arrangements, human actions can still count as free since, had the agent acted differently, the past or the natural laws would have been different. If so, it is hard to see why Molina argues so fiercely for theological compatibilism yet emphatically endorses causal, or nomological, incompatibilism. If it suffices for a human action to be free (in the sense relevant to moral responsibility) that the agent enjoy counterfactual power over the corresponding divine beliefs, why should it not also suffice for human freedom with respect to deterministic laws and the past that the agent have counterfactual power over such conditions? ${ }^{24}$ If the Molinist would countenance such a power, however, he might jeopardize his libertarianism. For in that case an action's being causally determined would not prevent it from qualifying as free, or its agent's being morally responsible for it.

In order to respond to this problem, the Molinist will have to show that, on closer inspection, these two kinds of power are in fact relevantly different. He must convincingly argue that, while it is sufficient for a human agent to act freely that he enjoys counterfactual power over

${ }^{23}$ Here I am indebted again to Brüntrup and Schneider. For more on this problem see their (2011).

${ }^{24}$ For a classic argument to the effect that we enjoy such power over the laws of nature see Lewis (1986). 
eternal divine beliefs, a similar power over the past and deterministic laws of nature does not suffice to guarantee freedom (in the sense relevant to moral responsibility). I think that such an argument may be found. After all, atemporal divine beliefs are ontologically different entities from laws of nature and contingent temporal states of affairs. What such an argument would look like, however, is a topic for another paper. ${ }^{25}$

\section{BIBLIOGRAPHY}

Brüntrup, Godehard, S.J., and Ruben Schneider. 2011. 'How Molinists Can Have Their Cake and Eat it Too', in The Ways Things Are - Studies in Ontology, ed. by Christian Kanzian, Winfried Löffler and Josef Quitterer (Heusenstamm: Ontos), pp. 221-239

Fischer, John Martin. 2008. 'Molinism', in Oxford Studies in Philosophy of Religion, vol. I, ed. by Jonathan Kvanvig (Oxford: Clarendon Press), pp. 18-43 Fischer, John Martin. 2009. 'More on Molinism', in Metaphysics and God: Essays in Honor of Eleonore Stump (New York: Routledge), pp. 27-40

Fischer, John Martin. 2011. 'Putting Molinism in its Place', in Molinism: The Contemporary Debate, ed. by Ken Perszyk (Oxford: Oxford UP), pp. 208-226 Fischer, John Martin, and Mark Ravizza, S.J. 1998. Responsibility and ControlA Theory of Moral Responsibility (Cambridge: Cambridge University Press) Freddoso, Alfred. 1988. Introduction, in Luis de Molina, On Divine Foreknowledge (Part IV of the Concordia) (Cornell: Cornell University Press), pp. 1-81

Jäger, Christoph. 2011a. 'Molina on Foreknowledge and Transfer of Necessities', in God, Eternity, and Time, ed. by Edmund Runggaldier and Christian Tapp (Farnham: Ashgate), pp. 81-96

Jäger, Christoph. 2011b. 'Scientia Media and Freedom to Do Otherwise', in The Ways Things Are - Studies in Ontology, ed. by Christian Kanzian, Winfried Löffler and Josef Quitterer (Heusenstamm: Ontos), pp. 241-262

Lewis, David. 1981. 'Are We Free to Break the Laws?', Theoria, 47: 113-21, repr. in Philosophical Papers, vol. II (New York, Oxford: Oxford UP, 1986), pp. 291-98

Molina, Luis de, S.J. (Concordia). Liberi Arbitrii cum Gratiae Donis, Divina Praescientia, Providentia, Praedestinatione et Reprobatione Concordia,

${ }^{25}$ For helpful comments I am indebted to the participants of the conference 'Minds: Human and Divine', organized by Godehard Brüntrup, August 6-9, 2012, at Fürstenried Palace in Munich, and to the participants of a workshop with John Martin Fischer on November 29 in Innsbruck. Special thanks for discussions of the present material go to John Martin Fischer, Katherine Munn, Ruben Schneider, and Patrick Todd. Work on this essay has been supported by a research grant from the Province of Bozen, South Tyrol. 
critical edition of the second edition from 1595, ed. Johann Rabeneck, S.J. (Oña and Madrid: Collegium Maximum S.J., Soc. Edit. 'Sapientia', 1953). English translation of part IV by Alfred Freddoso, in Luis de Molina, On Divine Foreknowledge (Part IV of the Concordia) (Cornell: Cornell University Press, 1988), pp. 85-273

Pike, Nelson. 1965. 'Divine Omniscience and Voluntary Action', The Philosophical Review, 74: 27-46

Ravizza, Mark, S.J. 1994. 'Semi-Compatibilism and the Transfer of Nonresponsibility', Philosophical Studies, 75: 61-93

Stump, Eleonore, and John Martin Fischer. 2000. 'Transfer Principles and Moral Responsibility', in Philosophical Perspectives, 14, Action and Freedom (Malden, MA; Oxford: Blackwell), pp. 47-55

Stump, Eleonore, and Norman Kretzmann. 1981. 'Eternity', The Journal of Philosophy, 78: 429-458

Swinburne, Richard. 1993a. The Coherence of Theism, revised ed. (Oxford: Clarendon Press)

Swinburne, Richard. 1993b. 'God and Time', in Reasoned Faith - Essays in Philosophical Theology in Honor of Norman Kretzmann, ed. by Eleonore Stump (Ithaca, London: Cornell University Press), pp. 204-222

Van Inwagen, Peter. 1983. An Essay on Free Will (Oxford: Oxford UP)

Van Inwagen, Peter. 1989. 'When is the Will Free?', Philosophical Perspectives, 3, quoted from Agent, Causes, and Events, ed. by Tim O'Connor (Oxford, New York: Oxford UP, 1995), pp. 219-269

William of Sherwood. 1995. Introductiones in logicam, ed. by Hartmut Brands and Christoph Kann (Hamburg: Meiner)

Zagzebski, Linda Trinkaus. 1991. The Dilemma of Freedom and Foreknowledge (Oxford: Oxford UP)

Zagzebski, Linda Trinkaus. 2002. 'Recent Work on Divine Foreknowledge and Free Will', in The Oxford Handbook on Free Will, ed. by Robert Kane (Oxford: Oxford UP), pp. 45-64

Zagzebski, Linda Trinkaus. 2011. 'Eternity and Fatalism', in God, Eternity, and Time, ed. by Edmund Runggaldier and Christian Tapp (Farnham: Ashgate), pp. $65-80$ 